\title{
The Mediating Role of Organizational Cynicism in the Relationship between Workplace Incivility and Organizational Silence
}

\author{
Hasan Tutar ${ }^{1}$, Ferruh Tuzcuoğlu ${ }^{2}$, Teymur Sarkhanov ${ }^{3,4}$ \\ ${ }^{1}$ Bolu Abant Izzet Baysal University, Public Relations Department, Bolu, Turkey \\ ${ }^{2}$ Sakarya University, Department of Political Science and Public Administration, Sakarya, Turkey \\ ${ }^{3}$ Azerbaijan State University of Economics (UNEC), Department of Economics and Business Administration, \\ Baku, Azerbaijan \\ ${ }^{4}$ Sakarya University Graduate School of Business, Sakarya, Turkey
}

\begin{abstract}
In this study, the mediating role of "organizational cynicism" in the relationship between "rudeness in the workplace" and "organizational silence" was examined. The research is a quantitative research cross-sectional study. Research data were collected using a simple random sampling technique. Data analysis shows a significant and positive relationship between the participants' perceptions of rudeness in the workplace and organizational silence. It is understood that the perception of organizational cynicism also mediates this relationship. It was understood that the high perception of the workplace laziness of the participants caused the perception of organizational silence to be high.
\end{abstract}

Keywords - Organizational behavior, organizational psychology, workplace incivility, organizational silence, organizational cynicism.

DOI: $10.18421 /$ TEM102-11

https://doi.org/10.18421/TEM102-11

Corresponding author: Hasan Tutar,

Bolu Abant Izzet Baysal University, Public Relations

Department, Bolu, Turkey.

Email: hasantutar@ibu.edu.tr

Received: 13 March 2021.

Revised: 23 April 2021.

Accepted: 29 April 2021.

Published: 27 May 2021.

(cc) BY-NC-ND (C) 2021 Hasan Tutar, Ferruh Tuzcuoğlu \& Teymur Sarkhanov; published by UIKTEN. This work is licensed under the Creative Commons AttributionNonCommercial-NoDerivs 4.0 License.

The article is published with Open Access at www.temjournal.com

\section{Introduction}

Problems experienced in organizations are generally expressed as counterproductive work behaviors in the organization literature. In business life, impolite, rude, and disrespectful behavior negatively affects the organization and employee's psychology. Nonchalant behaviors also cause the organizational climate to be more stressful, and the organizational health deteriorates [1], [2]. Problems experienced in organizations are generally expressed as counterproductive work behaviors in the organization literature. In business life, impolite, rude, and disrespectful behavior negatively affects the organization and employee's psychology. Nonchalant behaviors also cause the organizational climate to be more stressful and the organizational health to deteriorate.

Workplace incivility is all kinds of attitudes and behaviors that violate courtesy rules in the workplace and violate organizational norms. However, it should be noted that incivility is not aggression or conflict; they are rude and disrespectful behavior that is not expected from civilized people. Workplace incivility, one of the anti-productive work behaviors, is less harmful than aggressive behavior [3]. Although the intensity of unkind organizational behavior is low, if it continues, it may cause loss of motivation, low performance, strengthening of the intention to quit, and organizational cynicism. Various studies have been carried out regarding the fact that in environments with instinctive incivility and incivility, people react to the said impolite sometimes with organizational cynicism and sometimes with organizational silence [4], [5].

Organizational silence is that employees avoid making and expressing various contributions and thoughts in favor of the organization. Employees do 
not express their suggestions or opinions about the organization because they are afraid of possible reactions, and they show indifference and unresponsiveness in organizational matters. However, the silence of the employees in organizational silence is not adapting or obeying, but deliberately they are not showing the reaction they should show in favor of the organization [6], [7], [8]. Thus, organizational silence is not a "silent" personality trait but a state of inertia that is shown consciously and deliberately. Employees can sometimes be silent because they do not have any thoughts; this kind of silence is not organizational silence.

Organizational silence has the negative side when it avoids employees' intellectual capital. Due to organizational silence, organizations lose the opportunity to benefit from their employees' psychological and mental powers. Also, organizational silence harms not only organizations but also employees who remain silent. Because of organizational silence, employees who feel stressed, irritated, indifferent, and excluded may feel resentment towards their managers and other employees [9]. As the atmosphere of loudness prevails in the organization, people start to increase negative feelings, which causes them to show attitudes and behaviors towards the organization and its employees. Organizational cynicism is the employees' general tendency to show opposing attitudes and behaviors in all matters due to these negativities.

Organizational cynicism is that employees take a critical attitude towards organizational matters, thinking that their organizations do not act by honesty, truthfulness, fairness, and general ethical codes or dissatisfaction. It is a constant opposition attitude towards the organization and its employees. Organizational cynicism is a set of attitudes symbolized by disappointment and distrust towards the organization. It is the employees' critical attitude towards the organization due to violations of the psychological contract, injustice, unbalanced distribution of power within the organization, inability to participate in the decision-making process, long working hours, and mobbing lousy management, organizational change, and lack of communication. Studies on organizational cynicism show that cynicism causes many negative behaviors, both organizational and individual [10], [11]. While organizational cynicism causes emotions such as frustration, hopelessness, disappointment, and pessimism in the employee, on the other hand, it can lead to various criticisms such as the disdainful attitude of the employees towards their organizations, not rationalizing the decisions taken by the organization, and accusing the organization management of not acting by ethical codes. Also, problems such as indifference towards the organization and the job, strengthening intention to quit, resignation, despair, distrust of colleagues, disappointment, low performance, and burnout are attitudes and behaviors stemming from organizational cynicism.

This study is aimed to examine the concepts of "workplace incivility," "organizational silence," and "organizational cynicism" as anti-productive behaviors. It is thought that the research can make significant contributions to those who work on organizational psychology, practitioners, researchers, and organizational policymakers. The research results have an essential aim to draw attention to the positive organizational behaviors that have an essential role in the high performance of the employees and the counterproductive work behaviors that reduce their motivation and productivity. For this purpose, the central question of whether organizational cynicism functions as a tool in the relationship between organizational incivility and employee's silence is tried to be answered. The theoretical basis of the research, workplace indolence, is based on the frustration-aggression theory developed by Dollar and Miller [12] Organizational silence is based on the "SelfAdaptation Theory" developed by Premeaux and Bedeian [13] and organizational cynicism is based on the emotional event theory developed by Weiss and Cropanzano [14].

\section{Theoretical Framework}

\subsection{Workplace Incivility}

Workplace incivility is not a situation that happens instantly, comes and goes, and appears infrequently, but rude behaviors which show continuity and cause the employees to feel uncomfortable. Unlike other negative behaviors such as bullying, harassment, aggression, swearing, and intimidation in the workplace, workplace incivility is rude behavior that violates business rules for mutual respect in a workplace and psychologically batters a person. Although there are different opinions about what behaviors are unkind in a workplace, any uncivilized behavior, rude and free of respect, can be seen as workplace incivility. Examples of impolite behavior include yelling at people at work, ignoring colleagues' thoughts, excluding colleagues, ignoring them, speaking threateningly and suggestively, and snorting people [15], [16]. Also, it includes verbal behaviors such as gossiping, spreading rumors, and being hurtful in the workplace; it includes actual behaviors such as ignoring coworkers and staring. 
Impolite behavior can be less harmful than deviant, anti-social, aggressive, or anti-productive work behavior in the workplace but it can be devastating when it persists. Violating respect rules and not obeying the minimum courtesy rules have an essential role in the emergence of workplace incivility. Workplace incivility between the parties can be experienced in two different ways. First, lowlevel rude behaviors are mutually perpetuated, and over time, incivility can lead to conflicts. The person perceives impudence as a threat to himself. Depending on this perception's severity, the individual may turn to various destructive behaviors such as aggression, violence, and variety [17], [18]. If superiors behave unkindly towards subordinates, workplace incivility may turn into organizational conflict. Thus, workplace incivility is one of the main reasons for the emergence of a hostile climate in organizations. Many studies have shown that workplace indolence is associated with burnout syndrome, low organizational commitment, absenteeism, and intention to quit [4], [5]. Workplace indolence also increases the disagreement between organizational employees and organizational norms.

\subsection{Organizational Silence}

Organizational silence is the fear of employees expressing their opinions on organizational problems. Employees who can provide organizational benefits do not express their opinions and do not take any initiative in favor of the organization. Organizational silence is divided into two parts: "acquiescent silence" and "quiescent silence". Submissive silence is when the individual keeps his thoughts to himself based on the acceptance of something unpleasant. On the other hand, calm silence is the individual's silence to protect himself, based on fear of the harmful consequences he may face in the event of his speech [19], [20]. Although there are things that the employee can do about organizational problems, they refrain from doing them and do not say their thoughts deliberately. Being passive, ineffective, and unresponsive is the basis of silence. Organizational silence is purposeful, active, and conscious action.

Organizational silence can be considered in two basic dimensions. The first is that employees remain silent, and the second is that employees are forced into silence. Organizational silence is that employees do not react, do not speak, express an opinion and act intentionally, although they have the words to say and their contributions to offer. In organizations where organizational silence is experienced, organizations lose the opportunity to benefit from their mental labor and intellectual capital. On the other hand, employees cannot find the opportunity to realize themselves because they are below their potential, and their intention to quit is strengthened by losing job satisfaction and motivation [21], [22]. In the case of being left silent, employees are forced into silence not because they want to, but because they are forced to remain silent due to the organizational climate, culture, and management style.

There can be many reasons for organizational silence. The silent situation may be mostly caused by psychological reasons such as the absence of a psychological contract between the person and the organization, the employee's lack of organizational commitment, and the lack of organizational citizenship. Lack of a democratic management approach in organizations feeds organizational insecurity. In an unsafe environment, employees may turn to silence for protection and protection. The dislike of some managers to express the problems in the organization may also cause organizational silence. Also, seeing the conversation as risky is an important reason for organizational silence. Employees may not express their opinions openly due to fear of isolation, inability to be promoted, and exclusion. When employees talk about a negative situation with their colleagues, they may think that their relationships will deteriorate. In such cases, employees may prefer silence because they believe that a solution will not be produced even if they express their problems [23], [24], especially employees who cannot afford to confront the other side may inadvertently remain silent. Employees can remain silent in order to protect themselves against possible damages. In cases where they do not feel safe enough, they may prefer silence for protection.

\subsection{Organizational Cynicism}

Based on ancient Greek philosophy, the concept of cynicism means a general opposing attitude to events by activating negative feelings such as humiliation, anger, and shame. Generally, cynicism means skepticism, distrust, disbelief, and pessimism. It is an attitude that continually seeks fault, criticizes, does not like others, and does not trust. Organizational cynicism is a general opposition and negative attitude of the employee towards his/her organization. Organizational cynicism means that the individual has a negative and oppositional attitude and behavior towards everything in the organization. People who show cynicism think that people are insecure and insincere [25], [26]. These people are people who are frequently critical, hardy and pursuing faults. It is an expected situation that the cynicism tendencies will increase when the employees think that their organizations are far from honesty and justice.

According to cynicisms, nothing is going well in the organization, a general state of corruption and decay is experienced. It is controversial whether organizational cynicism is a personality trait or an attitude stemming from its situation because of his experiences. Some argue that cynicism is a judgment acquired because of a person's experience and that it is a learned attitude rather than a personality trait. Organizational cynicism for them can be person- 
oriented, professional-oriented, organization oriented and managerial-oriented. Unlike feature-based trends such as personal cynicism, organizational cynicism is often a situation factor. They argue that people do not decide to be cynical and that organizational cynicism stems from bad experiences [27], [28]. In organizational cynicism, there is a strong sense of insecurity towards the organization. According to them, the organization is the place where all kinds of injustice are institutionalized.

Organizational cynicism, which is described as a negative attitude towards the organization, has three dimensions: cognitive, affective, and behavioral. Cognitive dimension comprises a cognitive judgment that the organization lacks honesty, which emerges with negative emotions such as anger, contempt, and condemnation. In this respect, cynicism tends to rise disbelief about the goodness and sincerity of actions and human motives. According to cynicism, they believe that their organizations are doing them wrong due to the lack of principles such as justice, honesty, and sincerity in organizations. The emotional dimension of organizational cynicism includes strong emotional responses such as disrespect, anger, distress, and shame. In addition to negative thoughts and beliefs, this type of cynicism also has strong emotional responses such as contempt and anger. Individuals with high organizational cynicism levels may feel boredom and shame when they think about their organization [29]. The behavioral dimension includes the behaviors of making robust, disparaging, and disparaging criticisms of the organization.

\section{Methodology and Procedures}

\subsection{Research Design}

The research is a cross-sectional study conducted according to the relational survey design, one of the quantitative research designs. Research data were collected according to the simple random sampling technique, and the collected data were analyzed according to descriptive and statistical techniques. IBM SPSS 22 and IBM AMOS 25 package programs were used in the analysis of the data. In the study, the mediating effect of "organizational cynicism" in the relationship between "workplace incivility" and "organizational silence" was examined.

\subsection{Participants and Sampling}

The data used within the study's scope were obtained from full-time employees operating in service enterprises in Ankara. The research sample was determined according to the random sampling technique. The random sampling technique was chosen because each unit of the target population could be represented in the sample with equal probability. The remaining 455 questionnaires were evaluated after eliminating the erroneous and deficient data among the collected data. Expressions in the scales are in 5-point Likert format, and the grading is "strongly disagree" (1) and "strongly agree" (5).

\subsection{Process and Analysis}

IBM SPSS 22 and IBM AMOS 25 package programs were used to analyze the collected data. Cronbach's Alpha values were calculated to determine the scales' reliability and validity, and confirmatory factor analysis was applied. Structural equation modeling (SEM) was used to test the hypotheses. Analyzes have been made with the maximum likelihood method in SEM. The theoretical model suggested by SEM was tested.

\subsection{Data Collection Instruments}

In order to collect research data; Dyne et al. [30] 7item "Workplace Indolence Scale" developed by Gök et al. [31] and the "Organizational Silence Scale" consisting of 15 items and the "Organizational Cynicism Scale" with 14 items developed by Brandes [32] were used.

\subsection{Measurement Model and Hypotheses}

In the study, the following theoretical model and hypotheses were developed to assume that workplace indolence will strengthen organizational silence perception and that there will be a positive relationship between these two variables. The model assumes that workplace incivility will positively affect organizational silence, and organizational cynicism will function as a mediator. In the model, "workplace indolence" is considered as the independent variable, "organizational silence" as the dependent variable, and "organizational cynicism" as the mediating variable (Figure 1).

H1: Workplace incivility positively affects organizational silence.

H2: Organizational silence affects organizational cynicism positively.

H3: Workplace incivility positively affects organizational cynicism.

H4: Organizational cynicism plays a mediating role in the effect of workplace indolence on organizational silence. 


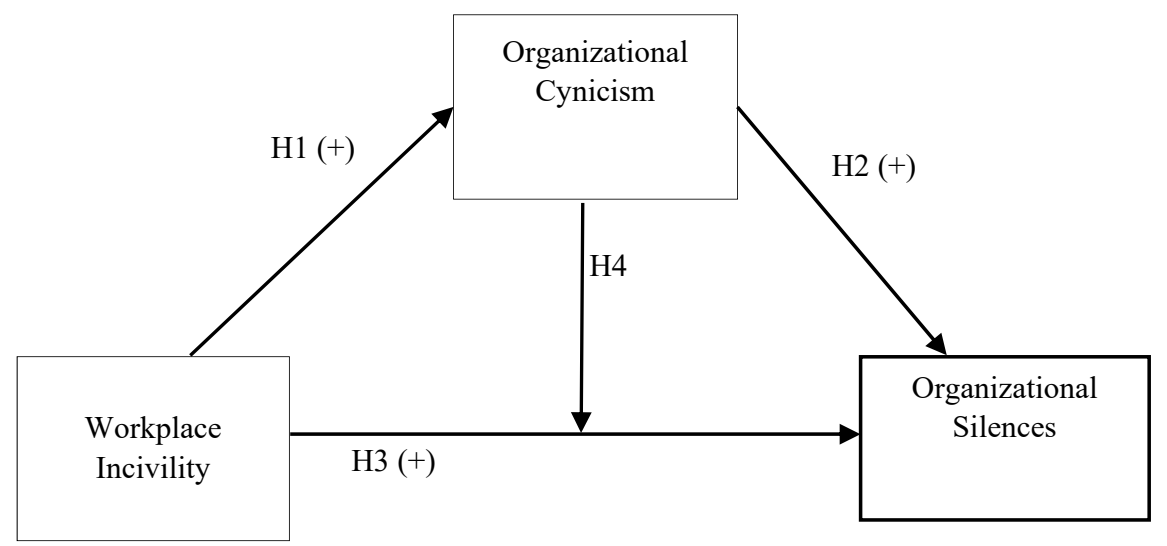

Figure 1. Research Model

\subsection{Validity and Reliability of Research}

Within the scope of the research, firstly, reliability analyzes of the scales were made. The values of $\alpha=$ 0.958 for the workplace indolence scale, $\alpha=0.842$ for the organizational silence scale, and $\alpha=0.947$ for the organizational cynicism scale were obtained. These values show that the scales are reliable.
Confirmatory factor analysis (CFA) was applied to the measurement model to determine the reliability and validity of the scales of workplace incivility, organizational silence, and organizational cynicism.

According to the CFA result, the fit indices $\chi 2 / D F$, GFI, NFI, CFI, TLI, RMSEA values, good fit indices, and validity values are shown in Table 1 .

Table 1. Model-Data Fit Values

\begin{tabular}{ccc}
\hline Data-Model Fit Indices & Acceptable Indices & Single Factor Model Indices \\
\hline Chi-Square $(\chi 2)=748,64$ & & Chi-Square $(\chi 2)=4246,49$ \\
$\mathrm{DF}=452, \mathrm{p}<0.01$ & $\mathrm{GFI}>0.90$ & $\mathrm{DF}=594$ \\
$\mathrm{GFI}=0.891$ & $\mathrm{NFI}>0.90$ & $\mathrm{GFI}=0.384$ \\
$\mathrm{NFI}=0.901$ & $\mathrm{CFI}>0.90$ & $\mathrm{NFI}=0.475$ \\
$\mathrm{CFI}=0.952$ & $\mathrm{TLI}>0.90$ & $\mathrm{TLI}=0.510$ \\
$\mathrm{TLI}=0.948$ & $\mathrm{RMSEA}<0.08$ & $\mathrm{RMSEA}=0.160$ \\
$\mathrm{RMSEA}=0.052$ & $\chi 2 / \mathrm{DF}<5$ & $\chi 2 / \mathrm{DF}=7.149$ \\
$\chi 2 / \mathrm{DF}=1.656$ &
\end{tabular}

Source: [33], [34], [35], [36].

According to the 3 -factor model specified in Table $2, \chi^{2}$ value is seen to be significant $(p<0.01)$. Also, $\chi 2 / \mathrm{DF}$ value (1.656) below 5 indicates that the model meets the fit criteria. It is seen that the data are consistent in terms of GFI $=0.891, \mathrm{CFI}=0.952$, NFI $=0.901$, TLI $=0.948$ and RMSEA $=0.052$. The comparative harmony table between the single-factor model and the multi-factor model is shown in Table 1. As a result of CFA, the "Chi-Square Difference Test" was applied to determine the difference between the three-factor model (workplace indolence, organizational silence, and organizational cynicism) and the one-factor model in terms of compliance, and it was found that the difference between $\chi 2$ values was significant. According to this result, it was determined that there was no common method deviation in the data. According to this finding, it was concluded that the data were compatible according to the 3 -factor model.

The organizational cynicism scale was excluded from the analysis because factor loads of the $6^{\text {th }}, 10^{\text {th }}, 13^{\text {th }}$, and $14^{\text {th }}$ questions among the scale questions considered within the analysis scope were less than 0.5. In the study, divergence and convergence differential validity analyses were performed to determine the variables' values by measuring the scale expressions. In this framework, it was seen that all variables of the validity-oriented structure of a model that was investigated showed low correlation with other variables, providing convergent validity, which showed a high correlation with the discriminant validity (Table 2). 
Table 2. Average, Standard Deviation, Reliability and Correlation Values of the Variables

\begin{tabular}{lccccccc}
\hline Variables & Mean & SD & CR & AVE & 1 & 2 & 3 \\
\hline 1. Workplace incivility & 2.08 & .829 & .946 & .717 & - & & \\
\hline $\begin{array}{l}\text { 2. Organizational } \\
\text { cynicism }\end{array}$ & 2.01 & .687 & .933 & .584 & $.719^{* *}$ & - & \\
\hline $\begin{array}{l}\text { 3. Organizational } \\
\text { silences }\end{array}$ & 2.95 & .991 & .956 & .597 & $.359^{* *}$ & $25^{*}$ & - \\
\hline
\end{tabular}

Note: SD, Standard Deviation; *Significant at 0.05 level (bi-directional), ** Significant at 0.01 level (bi-directional)

In Table 2, the convergence validity of the data obtained in the research scales according to the AVE (Average explained variance) values is indicated. For a research model to provide convergent validity, the correlation level between scales has to be found [37]. The fact that the AVE values of the research model are higher than 0.5 indicates that the relevant items are valid in the implicit variable. As can be seen in Table 2, convergence validity is provided with AVE values higher than 0.5. Also, the correlation value between scales should be less than 0.80 to determine discriminative validity [37]. The correlation values between the study variables are lower than 0.80 , and the significant relationship shows that the divergence discriminant validity is provided. However, according to, the standardized factor loadings has to be higher than 0.5 in order for the research model to be compatible [38]. The standardized factor loads of the research scale expressions range from 0.66 to 0.89 . Also, the parametric test $t$ values of these factor values between 7.23 and 10.48 show that the research model is compatible.

Table 2 shows a positive correlation between organizational cynicism and workplace indolence according to Pearson Correlation analysis $(r=.719$ $\mathrm{p}<.001)$. It is seen that there is a positive relationship between organizational cynicism and organizational silence $(\mathrm{r}=.325, \mathrm{p}<.001)$. There is a positive correlation between workplace indolence and organizational silence $(\mathrm{r}=.359, \mathrm{p}<.001)$. When the correlation values are examined, it is seen that there are significant relationships between variables.

\section{Results}

\subsection{Demographic Findings}

The study participants' demographic information such as gender, education level, age, and seniority are explained in Table 3.

Table 3. Demographic Findings

\begin{tabular}{cccccc}
\hline Gender & Frequency (n) & Percent (\%) & Marital Status & Frequency (n) & Percent (\%) \\
\hline Female & 184 & 40,40 & Single & 146 & 32,09 \\
\hline Male & 271 & 59,60 & Married & 309 & 67,91 \\
\hline Total & 455 & 100,00 & Total & 455 & 100,00 \\
\hline Age & Frequency (n) & Percent $(\%)$ & Education Status & Frequency (n) & Percent (\%) \\
\hline $18-25$ & 78 & 17,14 & High school & 55 & 12,09 \\
\hline $26-35$ & 142 & 31,21 & License & 170 & 37,36 \\
\hline $36-45$ & 114 & 25,05 & Master & 169 & 37,14 \\
\hline $46-55$ & 97 & 21,32 & Doctorate & 61 & 13,41 \\
\hline 56 above & 24 & 5,28 & & & \\
\hline Total & 455 & 100,00 & Total & 455 & 100,00 \\
\hline
\end{tabular}

$40.4 \%$ of the participants are women, and $59.6 \%$ are men. $32 \%$ of the participants are single, and $67.9 \%$ are married. Participants are mostly between the ages of $26-35(31.2 \%) .37 .3 \%$ of the participants are undergraduate, and $37.1 \%$ graduate.

\subsection{Testing Research Hypotheses}

The structural equation model was applied to the research data with the AMOS program to test research hypotheses. Table 4 shows the direct impact results as a result of the Structural Equation Model analysis. 
Table 4. Direct Impact

\begin{tabular}{lcccc}
\hline \multicolumn{1}{c}{ Variables } & $\beta$ & $\mathrm{t}$ & $\mathrm{SE}$ & $\mathrm{P}$ \\
\hline Workplace Incivility - Organizational Cynicism & 0,719 & 16,033 & 0,037 & $* * *$ \\
\hline Organizational Cynicism - Organizational Silences & 0,139 & 2,610 & 0,124 & .002 \\
\hline Workplace Incivility - Organizational Cynicism & 0,259 & 3,005 & 0,103 & .003 \\
\hline
\end{tabular}

Note: SE, standard error; * $0.05 * * 0.01 * * *$ Significant at 0.001 level (bi-directional)

According to Table 4, workplace incivility positively affects organizational cynicism $(\beta=.719, \mathrm{t}$ $=16.033, \mathrm{p}<0.001)$. These values mean that people have a critical attitude towards the organization to the extent that they are exposed to incivility in their organizations. These results also show that the $\mathrm{H} 1$ hypothesis that workplace indolence positively affects organizational silence is confirmed. According to the research findings, it is seen that organizational cynicism has a positive and significant effect on organizational silence $(\beta=.139, \mathrm{t}=2.610$, $\mathrm{p}<0.01)$.
These values show that the $H 2$ hypothesis that organizational silence positively affects organizational cynicism is supported. This finding means that all attitudes and behaviors that disrupt the organizational climate and health are processes that feed each other.

It is understood that the workplace indolence independent variable has a significant positive effect on the organizational cynicism tool variable $(\beta=$ $.259, \mathrm{t}=3.005, \mathrm{p}<0.01)$. These values show that the $H 3$ hypothesis, which was established as workplace indolence affects organizational cynicism positively, is supported (Figure 2).

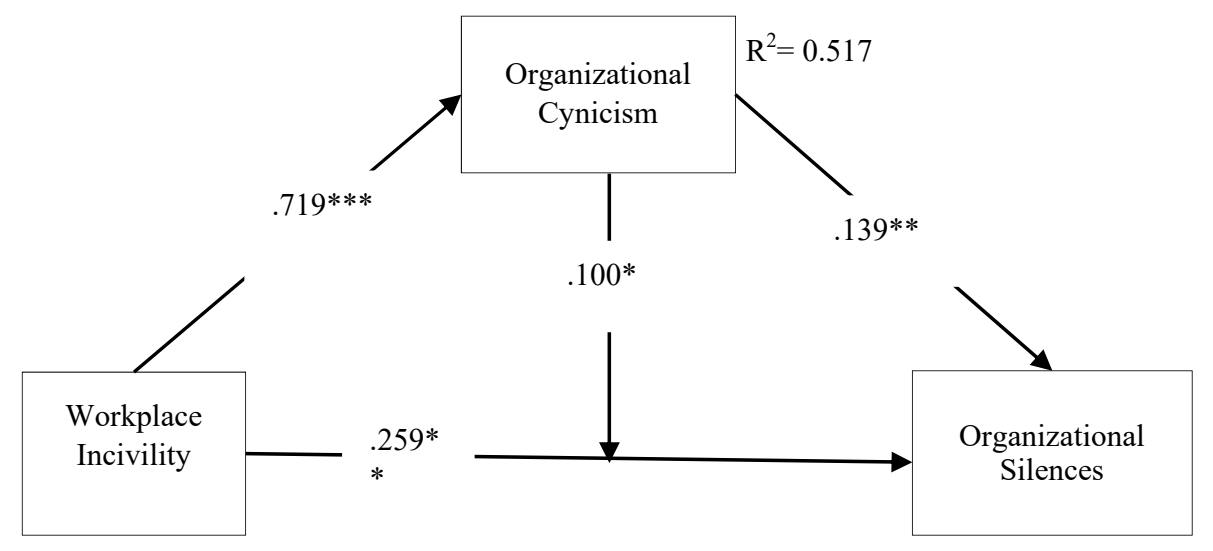

Figure 2. Structural Equation Model Results

In the study, workplace incivility on organizational silence was examined without including organizational cynicism in the model. According to the findings, workplace incivility positively and significantly affects organizational silence $(\beta=.259$, $\mathrm{p}<0.001)$. When organizational cynicism is included in the model as a mediating variable, workplace indolence positively and significantly affects organizational silence $(\beta=.359, \mathrm{p}<0.05)$. When this value is included in the organizational cynicism model, which is the mediator variable, the effect of the independent variable (organizational indolence) on the dependent variable (organizational silence) decreases $(\dot{c}<\mathrm{c})$. This situation shows that organizational cynicism has a partial mediating role in the relationship between workplace incivility and organizational silence.
Bootstrap method was used to test the role of mediator variables in the relationship between independent and dependent variables. Bootstrap technique creates a larger sample than the existing data set but with the same feature. This technique is used in mediation analysis to calculate indirect effects [39]. When Bootstrap estimates were analyzed at $95 \%$ confidence interval regarding the mediator effect of organizational cynicism, it was found that there was an increase in the positive effect of workplace indolence on organizational silence $(\beta$ $=0.10 ; 95 \%$ CI $[0.08$ to 0.20$\left.] ; \mathrm{R}^{2}=0.517\right)$. Since this effect differs significantly, it can be said that organizational cynicism has a partial mediator role $(\mathrm{p}$ $=0.032<0.05)$. According to this finding, it can be said that the $H 4$ hypothesis that organizational cynicism has a mediating role in the effect of workplace indolence on organizational silence is accepted. 


\section{Discussion and Conclusion}

This study aims to examine some variables that are considered anti-productive work behaviors in a different sample. The research, it is tried to answer the question of whether organizational cynicism functions as a tool in the relationship between organizational incivility and employee's silence. The research results show that there is a direct and mediating effect among the variables in question. According to the analysis findings, workplace incivility affects organizational cynicism positively $(p<0.001)$. Organizational cynicism, the mediator variable, positively affects organizational silence $(p=0.002<0.01)$. The research results show that workplace incivility, an independent variable, positively affects organizational silence $(p=0.003<0.01)$. Thus, it was understood that the research's theoretical model was a valid model and all hypotheses put forward for the research were confirmed. Analysis findings and the literature show that any counterproductive attitude and behavior that arise in the organization are not limited to itself; it turns into an organizational problem affecting many other factors. Research findings have to show that this is once again confirmed.

In this study, in which the role of organizational silence "mediator" in workplace indolence and organizational cynicism was examined, it was concluded that employees' perceptions of "workplace incivility" increased their perception of organizational cynicism, another anti-productive work behavior. On the other hand, it is seen that the perception of workplace incivility reinforces the organizational silence behavior of the employees. This situation shows that counterproductive attitudes and behaviors that disrupt the organizational climate and threaten organizational health in organizations are processes that feed each other. Also, the conclusion that the perception of organizational cynicism has a catalytic effect on the perception of organizational silence in the relationship between the dependent and the independent variable, it is understood that any counterproductive work behavior has a contagious effect and activates other counterproductive work behaviors.

\section{- Evaluation of Findings and Theoretical Implications}

In the literature, researches on workplace indolence, organizational cynicism, and organizational silence show that there is a consensus that these variables affect employees negatively. It is expected that workplace incivility positively affects organizational cynicism; people with a high perception of the workplace rude are expected to adopt a critical and negative attitude towards the organization. A study conducted in Jordan concluded that workplace incivility reinforces organizational cynicism [40]. Another study on nurses in Canada found a strong relationship between workplace incivility and organizational cynicism. In another study conducted in Jordan, it was found that workplace incivility increased perceptions of organizational cynicism [41]. These findings could be a consensus between this study's results and the literature, increasing its external validity. The study's second hypothesis determined that organizational cynicism positively affected organizational silence $(p=0.002<0.01)$. Organizational silence of organizational cynicism in a survey of nurses in Turkey has been affected in a positive direction [42]. Research on organizational cynicism with a high perception of nurses that organizational silence perception made in South Korea was high [43]. In a workplace survey on the nurses working in Turkey, it was determined to strengthen organizational incivility silence perception [44].

\section{- Practical Implications}

As in this study, which determines the partial mediator role of organizational cynicism in the effect of organizational silence of workplace indolence, no research has been found in the literature that examines three variables together. There are studies in which organizational cynicism plays a mediating role. For example, in a study, it was determined that organizational cynicism played a mediating role in the relationship between workplace incivility and information retention behavior [45]. However, it is seen that different variables are examined together in the study in question. In another study, it was determined that organizational cynicism played a mediating role in the relationship between workplace incivility and intention to quit [46]. Within this research framework, it is understood once again that any negative attitude and behavior in organizations affects many other negative behaviors; therefore, eliminating all kinds of counterproductive work behavior regardless of its size and effect is an essential organizational and managerial task.

\section{- Limitations and Avenues for Future Research}

The study sample consists of a limited number of people, and the research results are limited to the mentioned sample. Therefore, researching with different samples may yield different results. The research has been conducted in public institutions, and it is possible to reach different results in private sector organizations. The research is also quantitative correlational research; repeating the subject with qualitative and mixed research may increase its validity. In future studies, it may be useful to establish and test the model with different variables. 


\section{References}

[1]. Kapusuz, A. G., \& Biçer, M. (2018). Psikolojik sermayenin üretkenlik karşıtı iş davranışları üzerindeki olumlayıcı etkileri. Toros Üniversitesi IISBF Sosyal Bilimler Dergisi, 5(9), 229-249.

[2]. Yuan, Z., Barnes, C., \& Li, Y. (2018). Bad Behavior Keeps You Up at Night: Counterproductive Work Behaviors and Insomnia. Journal of Applied Psychology, 103(4), 383-398.

[3]. Demsky, C. A., Fritz, C., Hammer, L. B., \& Black, A. E. (2019). Workplace Incivility and Employee Sleep: The Role of Rumination and Recovery Experiences. Journal of Occupational Health Psychology, 24(2), 228-240.

[4]. Hershcovis, M., Cameron, A. F., Gervais, L., \& Bozeman, J. (2018). The Effects of Confrontation and Avoidance Coping in Response to Workplace Incivility. Journal of Occupational Health Psychology, 23(2), 163-174.

[5]. Kutlu, A., \& Bilgin, N. Turkish Reliability and Validity on Nurses of Workplace Incivility Scale. Journal of Health and Nursing Management, 4(2), 56-62.

[6]. Doo, E. Y., \& Kim, M. (2020). Effects of hospital nurses' internalized dominant values, organizational silence, horizontal violence, and organizational communication on patient safety. Research in Nursing \& Health, 43(5), 499-510.

[7]. Demirtas, Z. (2018). The Relationships between Organizational Values, Job Satisfaction, Organizational Silence and Affective Commitment. Online Submission, 4(11), 108-125.

[8]. Gündüz, Ş., \& Pekçetaş, T. (2018). Kuşaklar ve örgütsel sessizlik/seslilik. Işsletme Bilimi Dergisi, 6(1), 89-115.

[9]. Erdogdu, M. (2018). Effect of Organizational Justice Behaviors on Organizational Silence and Cynicism: A Research on Academics from Schools of Physical Education and Sports. Universal Journal of Educational Research, 6(4), 733-741.

[10]. Kim, S., Jung, K., Noh, G., \& Kang, L. K. (2019). What makes employees cynical in public organizations? Antecedents of organizational cynicism. Social Behavior and Personality: an international journal, 47(6), 1-10.

[11]. Rehan, M.; Iqbal, M.; Fatima, A.; Nawabl, S., (2017). Organizational cynicism and its relationship with employee's performance in teaching hospitals of Pakistan. Int. J. Econ. Manag. Sci., 6, 1-6.

[12]. Breuer, J., \& Elson, M. (2017). Frustrationaggression theory. The Wiley handbook of violence and aggression, 1-12.

[13]. Premeaux, S. F., \& Bedeian, A. G. (2003). Breaking the silence: The moderating effects of self-monitoring in predicting speaking up in the workplace. Journal of management studies, 40(6), 1537-1562.

[14]. Weiss, H. M., Cropanzano, R., (1996). “Affective events theory: A theoretical discussion of the structure, causes and consequences of affective experiences at work". In Staw, B. M., Cummings, L. L. (eds.), Research in Organizational Behavior, 18: 174. Greenwich, CT: JAI Press.
[15]. Alshehry, A. S., Alquwez, N., Almazan, J., Namis, I. M., \& Cruz, J. P. (2019). Influence of workplace incivility on the quality of nursing care. Journal of clinical nursing, 28(23-24), 4582-4594.

[16]. Shi, Y., Guo, H., Zhang, S., Xie, F., Wang, J., Sun, Z., ... \& Fan, L. (2018). Impact of workplace incivility against new nurses on job burn-out: a cross-sectional study in China. BMJ open, 8(4).

[17]. Hershcovis, M. S., Ogunfowora, B., Reich, T. C., \& Christie, A. M. (2017). Targeted workplace incivility: The roles of belongingness, embarrassment, and power. Journal of Organizational Behavior, 38(7), 1057-1075.

[18]. Armstrong, N. (2018). Management of nursing workplace incivility in the health care settings: A systematic review. Workplace health \& safety, 66(8), 403-410.

[19]. Yalçın, B., \& Baykal, Ü. (2019). Development and psychometric testing of the Organizational Silence Behavior Scale for healthcare professionals. Nursing \& health sciences, 21(4), 454-460.

[20]. Okeke-James, N. J., Igbokwe, I. C., Anyanwu, A. N., \& Obineme, O. P. (2020). Gender influence on school climate and organizational silence amongst teachers in Anambra State. European Scientific Journal, 16(10), 223-237.

[21]. Parcham, E., \& Ghasemizad, A. (2017). The impact of organizational culture on employees' organizational silence In Shiraz University of Medical Sciences. Journal of Health Management \& Informatics, 4(1), 25-30.

[22]. Hozouri, M., Yaghmaei, M., \& Bordbar, H. (2018). Clarifying the impacts of organizational silence on organizational commitment with controlling the effects of organizational rumors. Management Science Letters, 8(6), 533-542.

[23]. Bordbar, G., Shad, F. S., Rahimi, E., \& Rostami, N. A. (2019). Effect of Organizational Silence on Employees Productivity. International Journal of Management, Accounting and Economics, 6(3), 198207.

[24]. Hossein Amirkhani, A., \& Ghaleh Agha Babaei, F. (2017). The impact of organizational silence on organizational citizenship behavior. Management Studies in Development and Evolution, 26(85), 109124.

[25]. Sirin, Y. E., Aydin, Ö., \& Bilir, F. P. (2018). Transformational-Transactional Leadership and Organizational Cynicism Perception: Physical Education and Sport Teachers Sample. Universal Journal of Educational Research, 6(9), 2008-2018.

[26]. Tuna, R., Bacaksız, F. E., \& Seren, A. K. H. (2018). The effects of organizational identification and organizational cynicism on employee performance among nurses. International Journal of Caring Sciences, 11(3), 1707-1714.

[27]. Ozdem, G., \& Sezer, S. (2019). The relationship between solution-focused school leadership and organizational cynicism, organizational commitment and teachers' job satisfaction. International Journal of Progressive Education, 15(1), 167-183. 
[28]. Schmitz, M. A., Froese, F. J., \& Bader, A. K. (2018). Organizational cynicism in multinational corporations in China. Asia Pacific Business Review, 24(5), 620637.

[29]. Miller, T. (2018). Effects of transformational leadership on employee's organizational cynicism in an educational organization. [Doctoral dissertation]. Retrieved from: https://scholarworks.calstate.edu/concern/theses/jh343 t105. [accessed: 28 February 2021].

[30]. Dyne, L. V., Ang, S., \& Botero, I. C. (2003). Conceptualizing employee silence and employee voice as multidimensional constructs. Journal of management studies, 40(6), 1359-1392.

[31]. Gök, S., Karatuna, I., \& Başol, O. (2019). Reliability and Validity of the Turkish Version of the Workplace Incivility Scale. Turk Psikoloji Yazilari, 22(44), 116118.

[32]. Brandes, P. M. (1997). Organizational cynicism: Its nature, antecedents, and consequences. University of Cincinnati.

[33]. Hooper, D., Coughlan, J., \& Mullen, M. R. (2008). Equation modelling: Guidelines for determining model fit. Electronic Journal of Business Research Methods, 6(1), 53-60.

[34]. Schumacker, R. E., \& Lomax, R. G. (2010). A Beginner's Guide to. Structural Equation Modeling (3rd Edition), New York: Taylor \& Francis Group.

[35]. Waltz, C. F., Strickland, O. L., \& Lenz, E. R. (Eds.). (2010). Measurement in nursing and health research. Springer publishing company.

[36]. Wang, J., \& Wang, X. (2019). Structural equation modeling: Applications using Mplus. John Wiley \& Sons.

[37]. Kline, R. B. (2015). Principles and practice of structural equation modeling. Guilford publications.
[38]. Hair, J. F., Black, W. C., Babin, B. J., Anderson, R. E., \& Tatham, R. (2006). Multivariate data analysis. Uppersaddle River.

[39]. Sacchi, M. D. (1998). A bootstrap procedure for high-resolution velocity analysis. Geophysics, 63(5), 1716-1725.

[40]. Abubakar, A. M., Megeirhi, H. A., \& Shneikat, B. (2018). Tolerance for workplace incivility, employee cynicism and job search behavior. The Service Industries Journal, 38(9-10), 629-643.

[41]. Megeirhi, H. A., Ribeiro, M. A., \& Woosnam, K. M. (2020). Job search behavior explained through perceived tolerance for workplace incivility, cynicism and income level: A moderated mediation model. Journal of Hospitality and Tourism Management, 44, 88-97.

[42]. Çaylak, E., \& Altuntas, S. (2017). Organizational silence among nurses: The impact on organizational cynicism and intention to leave work. Journal of Nursing Research, 25(2), 90-98.

[43]. Kim, H. J., Jo, Y. G., \& Lee, J. W. (2018). The effects of trust in supervisor, work intensity and organizational cynicism on organizational silence in clinical nurses. Journal of the Korea AcademiaIndustrial cooperation Society, 19(12), 627-635.

[44]. Kumral, T. (2017). İşyeri Nezaketsizliği ve Örgütsel Sessizlik İlişkisinde Örgütsel Dişlanmanın Aracı Rolü. (Yayınlanmamış Yüksek Lisans Tezi). Marmara Üniversitesi, İstanbul..

[45]. Aljawarneh, N. M. S., \& Atan, T. (2018). Linking tolerance to workplace incivility, service innovative, knowledge hiding, and job search behavior: The mediating role of employee cynicism. Negotiation and Conflict Management Research, 11(4), 298-320.

[46]. Manzoor, M. T., Manzoor, T., \& Khan, M. (2020). Workplace incivility: a cynicism booster leading to turnover intentions. Decision, 1-9. 